(c) www.ijrbat.in

\title{
A STUDY ON QUALITATIVE AND QUANTITATIVE ANALYSIS OF ZOOPLANKTON AND PHYTOPLANKTONS OF RAJURA LAKE, DISTRICT AMRAVATI
}

\author{
Jayshri Chavan ${ }^{1}$, Umesh Meshram² and Lokesh Wankhade ${ }^{2}$ \\ 1. Model Junior College, Karanja (Ghadge), District Wardha-442203 \\ 2. Narayanrao Kale Smruti Model College, Karanja (Ghadge), District Wardha- \\ 442203 \\ email: jrchauvan@gmail.com
}

Communicated: 19.03.21

\begin{abstract}
:
The present study was carried out to study the qualitative and quantitative analysis of zooplankton and phytoplankton of Rajura lake of Amravati, District Amravati. The study was carried out for a period of 3 months viz. January, February and March 2012. In the present study 12 species of zooplankton and 10 species of phytoplankton were recorded. Out of 12 species of zooplankton 4 species belonging to protozoa, 4 species belong to rotifers, 4 species belong to crustacea. In case of phytoplankton out of 10 species, 4 species belong to Bacillariophyceae, 4 species belong to Chlorophyceae and 2 species belong to Myxophyceae. In the present study there were found monthly fluctuation in the number of zooplankton and phytoplankton. Maximum number of zooplankton and phytoplankton count was recorded in march month as compared to January and February.
\end{abstract}

Keywords: Zooplankton, Phytoplankton, Rajura.

\section{INTRODUCTION:}

Limnology is the study of inland water bodies (both saline and fresh) specially lakes, ponds and rivers (both natural and manmade) including their biological, physical, chemical and hydrological aspects. Plankton include all the microscopic organism which are suspended in water such as small plants (phytoplanktons), small animals (zooplanktons) and bacteria. The planktons occur in all the natural water as well as in the artificial impoundments like ponds, tanks reservoirs, irrigation channel etc. Many researchers have done the qualitative and quantitative analysis of zooplankton from various region of Maharashtra. Gharpure V and Bhatkulkar M (2015) have done the analysis of some zooplanktons with respect to seasonal variation from Vena River of District Nagpur. Kabra P D et al., (2016) have also studied the quantitative analysis of zooplanktons of fresh water ecosystem in washim town, District Washim. Tijare R V (2020) have done both qualitative and quantitative study of phytoplankton of Wainganga River, Markandadeo, District Gadchiroli. Khune CJ et al., (2020) have also reported the status of phytoplankton in relation to physico-chemcial characteristic of Siregaon lake, District Gondia. Joshi P (2011) have analysis the zooplanktons of Rajura lake of Buldhana district. Khan Rafiullah $\mathrm{M}$ and Pathan T D (2016) have studied the zooplankton diversity in Triveni lake at Amravati District.

The present study was carried out to study the qualitative and quantitative analysis of zooplankton and phytoplankton of Rajura lake of Amravati, District Amravati. 


\section{MATERIAL \& METHODS:}

A study on qualitative and quantitative analysis of zooplankton and phytoplankton was carried out. The site selected for the sampling is Rajura lake which is situated at a distance of $8 \mathrm{~km}$ south from Amravati city of District Amravati, Maharashtra. The Rajura lake covers the area of about 100 acres. The water sampling was carried out in 3 months viz. January, February and March. The biotic factors such as $\mathrm{pH}$, temperature, free $\mathrm{co}^{2}$ dissolved oxygen, chlorides, total alkalinity, total hardness, etc. were recorded and analyzed.

The water sample was collected 3 times a month. The collection of water sample was done at morning with the help of plankton nets of desired mesh size made of blotting cloth. The sample was allowed to settle by adding Lugol's solution and concentrated by centrifugation method. The concentrated sample was preserved in $4 \%$ of formalin solution. The isolation and transfer of plankton was carried out with the help of micropipettes. The material (Plankton) was wash twice or thrice in distilled water or saline solution and stained by adding few drops of aqueous eosin satin (1 $\mathrm{gm}$ eosin in $100 \mathrm{ml}$ of distilled water) for 10 minutes. After staining with aqueous eosin stain the material (Plankton) was washed with distilled water twice. The washed material was observed under microscope under high magnification for the quantitative estimation of zooplankton and phytoplankton.

\section{RESULT \& DISCUSSION:}

In the present study there were found monthly fluctuation and variation in the number of zooplankton and phytoplankton. The number of zooplankton and phytoplankton in the water of Rajura lake was found to be influenced by the physio-chemical parameters of water. The temperature recorded was range from $22^{\circ} \mathrm{C}-25^{\circ} \mathrm{C}$. The maximum temperature was recorded during march. The $\mathrm{pH}$ of the water recorded was alkaline (8.4 - 8.5). The dissolved oxygen level and free co ${ }^{2}$ was varied from $6.3-6.5 \mathrm{mg} / 1$ and $19.2-19.8 \mathrm{mg} / 1$ respectively. The hardness of water recorded was ranged from $160-162 \mathrm{mg} / 1$ which indicates that the Rajura lake is hard. (Table. 1)

Total 45 number of zooplankton and 39 number of phytoplankton was recorded during the study. Total 12 species of zooplankton were recorded, Protozoan (4), Rotifers (4), and Crustacean (4). The maximum number of zooplankton species was recorded from rotifers (17), followed by Protozoa (14) and Crustacean (14). (Table. 2). Khan Rafiullah M and Pathan T D (2016) have also reported the dominant of Rotifers among zooplankton from Triveni lake of Amravati.

The rotifers were found to be the most species rich group among the zooplanktons.

Total 10 species of phytoplankton were recorded, Bacillariophyceae (4), Chlorophyceae (4) and Myxophyceae (2). The maximum number of phytoplankton species was recorded from Chlorophyceae (17) followed by Bacillariophyceae (13) and Myxophyceae (9). (Table. 3). Tijare R V (2020) also reported the abundance presence of Chlorophyceae (15 species) among phytoplankton in Wainganga River, Markandadeo, District Gadchiroli. Khune CJ et al., (2020) also recorded the abundance species of chlorophyceae (18 species) among phytoplankton from

The Chlorophyceae were found to be the most species rich group among phytoplankton's, Siregaon lake, District Gondia.

Monthly fluctuation and variation were observed in number and species of zooplankton and phytoplankton. Maximum number of zooplankton (19) and phytoplankton (19) was recorded in month March as compared to January and February.

The abundance occurrence of the zooplankton and phytoplankton were found to be more in month of March as compared to the January and February, this is due to increased in temperature and availability of light. The increased in the temperature increased the activity of organism. The phytoplankton are the food of the zooplanktons are also found to be more in month of March as compared to January and February this is due to more availability of food. 
I J R B A T, Issue (IX), Vol. II, May 2021: 123-126

\section{CONCLUSION}

In the present study among zooplanktons, the rotifers were found to be the most dominant community while among phytoplankton, Chlorophyceae found to be the richest group.

The abundance of zooplanktons and phytoplankton in the Rajura lake indicates that the lake is productive.

\section{ACKNOWLEDGEMENT:}

Author is very thankful to Miss. Pratiksha Nitale for her valuable help during the project work. Author is also very thankful to Dr. S. D. Wagh, Associate Professor, Department of Zoology, Shri Shivaji Science College, Amravati for their valuable guidance during the project work.

\section{REFERENCES:}

Gharpure, V.L. and Bhatkulkar, M. (2015): Analysis of some zooplanktons with respect to seasonal variation from River Vena Dist. Nagpur, Maharashtra, India. Research Journal of Recent Sciences. 4: Pp 70-73.

Joshi, P. (2011): Studies of zooplanktons of Rajura Lake of Buldhana district, Maharashtra
OPEN $\bigcirc$ ACCES

e-ISSN $2347-517 X$

Original Article

India. Science Research Reporter. 1 (3): Pp132-137.

Kabra, P.D., Somatkar J.R and Dabhade D.S. (2016): Quantitative analysis of zooplanktons of fresh water ecosystem in Washim Town, Maharashtra, India. Indian Streams Research Journal. 6 (5): Pp 1-7.

Khan Rafiullah M and Pathan T.D. (2016): Study of zooplankton diversity in Triveni lake at Amravati district of Maharashtra. Journal of Global Biosciences. 5 (7): Pp 4315-4319.

Khune, C.J., Parwate B.P and Parshuramkar, B.B. (2020): Status of phytoplankton in relation to physico-chemical characteristic of Siregaon lake, Dist. Gondia (Maharashtra), India. International Research Journal of Science and Engineering. Special Issue A7: Pp 367-371.

Tijare, R.V. (2020): Qualitative and quantitative study of phytoplankton of River Wainganga near Markhandadeo, Dist. Gadchiroli (M.S). Environment Conservation Journal. 21 (3): Pp 43-49.

Table.1 Physiochemical analysis of Rajura Lake, Amravati

\begin{tabular}{|c|c|c|c|c|}
\hline \multirow{2}{*}{ Sr. No } & \multirow{2}{*}{ Parameters } & \multicolumn{3}{|c|}{ Values } \\
\hline & & January & February & March \\
\hline 1. & $\mathrm{pH}$ & 8.5 & 8.4 & 8.5 \\
\hline 2. & Temperature $\left({ }^{\circ} \mathrm{C}\right)$ & 22 & 23 & 25 \\
\hline 3. & TDS Mg/L & 215 & 216 & 214 \\
\hline 4. & Dissolved oxygen $(\mathrm{mg} / \mathrm{l})$ & 6.5 & 6.4 & 6.3 \\
\hline 5. & Free carbon dioxide $(\mathrm{mg} / 1)$ & 19.8 & 19.2 & 19.3 \\
\hline 6. & Chlorides (mg/l) & 56.2 & 56.6 & 56.4 \\
\hline 7. & Total alkalinity $(\mathrm{mg} / 1)$ & 144 & 145 & 147 \\
\hline 8. & Total Hardness (mg/1) & 160 & 161 & 162 \\
\hline 9. & Calcium Hardness (mg/1) & 92 & 92 & 93 \\
\hline 10. & Magnesium Hardness (mg/1) & 13 & 13 & 13 \\
\hline 11. & Sulphate (mg/1) & 34 & 34 & 34 \\
\hline 12. & Nitrate (mg/l) & 0.494 & 0.485 & 0.475 \\
\hline 13. & Phosphate (mg/l) & 0.031 & 0.030 & 0.032 \\
\hline
\end{tabular}

Table. 2 Recorded Population of Zooplankton of Rajura Lake, Amravati 


\begin{tabular}{|c|c|c|c|c|}
\hline \multirow{2}{*}{ Taxon } & \multicolumn{3}{|c|}{ Number of species } & \multirow{2}{*}{ Grand Total } \\
\hline & January & February & March & \\
\hline \multicolumn{5}{|l|}{ Protozoa } \\
\hline Euglena & 1 & 1 & 2 & 04 \\
\hline Paramecium & 1 & 1 & 2 & 04 \\
\hline Vorticella & 1 & 1 & 1 & 03 \\
\hline Ceratium & 1 & 1 & 1 & 03 \\
\hline Total & 04 & 04 & 06 & 14 \\
\hline \multicolumn{5}{|l|}{ Rotifers } \\
\hline Keratella & 2 & 2 & 2 & 06 \\
\hline Brachionus & 2 & 2 & 2 & 06 \\
\hline Asplanchna & 1 & 1 & 1 & 03 \\
\hline Filinia & 0 & 0 & 2 & 02 \\
\hline Total & 05 & 05 & 07 & 17 \\
\hline \multicolumn{5}{|l|}{ Crustaceans } \\
\hline Daphnia & 1 & 1 & 2 & 04 \\
\hline Moina & 1 & 1 & 2 & 04 \\
\hline Cyclops & 1 & 1 & 1 & 03 \\
\hline Nauplius & 1 & 1 & 1 & 03 \\
\hline Total & 04 & 04 & 06 & 14 \\
\hline Grant Total & 13 & 13 & 19 & 45 \\
\hline
\end{tabular}

Table. 3 Recorded Population of Phytoplankton of Rajura Lake, Amravati

\begin{tabular}{|c|c|c|c|c|}
\hline \multirow{2}{*}{ Taxon } & \multicolumn{3}{|c|}{ Number of species } & \multirow{2}{*}{ Grand Total } \\
\hline & January & February & March & \\
\hline \multicolumn{5}{|l|}{ Bacillariophyceae } \\
\hline Amphora & 1 & 1 & 1 & 03 \\
\hline Navicula & 1 & 1 & 2 & 04 \\
\hline Asterionella & 1 & 0 & 2 & 03 \\
\hline Synedra & 0 & 1 & 2 & 03 \\
\hline Total & 03 & 03 & 07 & 13 \\
\hline \multicolumn{5}{|l|}{ Chlorophyceae } \\
\hline Chlorella & 1 & 1 & 2 & 04 \\
\hline Closterium & 1 & 1 & 1 & 03 \\
\hline Denticula & 1 & 1 & 1 & 03 \\
\hline Spirogyra & 1 & 2 & 4 & 07 \\
\hline Total & 04 & 05 & 08 & 17 \\
\hline \multicolumn{5}{|l|}{ Myxophyceae } \\
\hline Anabaena & 1 & 1 & 2 & 04 \\
\hline Nostoc & 1 & 2 & 2 & 05 \\
\hline Total & 02 & 03 & 04 & 09 \\
\hline Grand Total & 09 & 11 & 19 & 39 \\
\hline
\end{tabular}

